\title{
STRUCTURE OF MATURE MIXED PINE-AND-SPRUCE STANDS ON POSTAGROGENIC LANDS IN LENINGRAD REGION, RUSSIA
}

\author{
Dmitry Danilov ${ }^{1}$, Natalia Belyaeva ${ }^{2}$, Sergey Janusz ${ }^{1}$ \\ ${ }^{1}$ Leningrad Scientific Research Institute of Agriculture "BELOGORKA”, Russia \\ ${ }^{2}$ Saint-Petersburg State Forest Technical University named after S.M. Kirov, Russia \\ stown200@mail.ru; galbel06@mail.ru; btkwood@mail.ru
}

\begin{abstract}
The objective of this study is to assess the qualitative and quantitative characteristics of pine (Pinus sylvestris) and spruce (Picea abies) stands growing on lands that were previously in agricultural use in the Leningrad region. Sample areas of mature mixed pine-and-spruce prevailing stands were studied. The taxation has revealed that the average height and diameter of the stands under study are greater than those in mixed modal stands of these species on forest lands. The analysis of the results of the study was performed by dispersion, correlation and ranking methods. To determine the competitive relationship between species, the coefficients of skewness, and kurtosis were calculated. For coniferous stands growing on former arable lands, the distribution of diameter classes for pine and spruce differ depending on the prevalence of species. The predominance of one of the coniferous species in the stands leads to an aggravation of competition, which manifests itself in positive coefficients of asymmetry. The skewness indicators and the kurtosis of tree trunks distribution clearly demonstrate the strengthening and weakening of competitive relationships in the stand. Competitive relationships between species are more balanced in stand compositions that include more than half of spruce and about $40 \%$ of pine, which results in the largest volume of stemwood. A more powerful root zone of trees in the former arable soil allows mixed stands of spruce and pine to produce a larger volume of wood than in pure stands of pine and spruce for the investigated region.
\end{abstract}

Key words: former arable land, taxation indicators, stands of spruce and pine, a series of distribution in terms of thickness, skewness and kurtosis.

\section{Introduction}

At present, the number of areas covered with tree vegetation on the lands formerly used in agricultural use is increasing. This trend is observed on most continents of the world, only the scale of what is happening is different. The reasons for this process have a social basis and are caused by a number of economic and political factors. In many European countries, the use of former agricultural land for the cultivation of cultivated stands of timber is an adopted land use practice. In Europe, there has been an increase in the forest area due to afforestation and forest expansion to abandoned agricultural lands since the 19th century. Secondary forest succession has played a significant role in changing the land cover in European mountains over the past few decades (McDonald et al., 2000). Natural shoot reforestation on former agricultural lands reflects a decline in traditional agricultural practices that can be observed all over the world. In Western Europe, this often occurs on fallow pastures and in places with steep slopes, poor soils or underdeveloped road infrastructure (Hansen et al., 2010).

In France, the process of reforestation is now mainly on the territory of agricultural land that is inconvenient for cultivation as well as on abandoned areas. For the last century the territory of forests in France has increased by 6 million hectares, despite the fact that during this time the volumes of forest extraction increased. The issue of abandoned agricultural land is of current interest in Mediterranean European countries, such as Spain, Portugal and
Italy. Already in 1950, it was observed that the land ceased to be used for traditional farming purposes as meadows, and arable land converted into naturally grown forests. This was mainly due to the fact that the areas are hilly and difficult to engage in agricultural activities. In these countries, afforestation is one of the most acceptable ways to use abandoned land. In Switzerland over the past few decades, the natural growth of forests has replaced most of the agricultural land in the Swiss mountains (Graf et al., 2005).

In Scandinavian countries, the use of postagrogenic land for the cultivation of forest plantations is an established practice.

In the countries of Eastern Europe over the past decades, the number of forest plantations on lands that were previously actively used in agriculture has increased. In the Czech Republic, the increase in the share of forests on former agricultural lands is associated with new land use changes and agricultural depressions in the 1990s (Macků, 2006). Nowadays investigations are carried out on the effect of natural regeneration of tree species on postagrogenic lands on the soil (Holubík et al., 2014), including the Polish Carpathians (Kozak, 2010).

In Poland on the whole, the extent of afforestation on state lands will be 4500 - 4600 hectares by 2020 . Forecasts show that the average annual area of afforestation on private lands will not exceed 2500 hectares by 2020. In general, we can expect that in Poland for the period 2015 - 2020 will be carried out reforestation of 20 thousand hectares of agricultural land. 
The abandonment of lands and the secondary succession of forests played a significant role in changing the soil and vegetation cover and increasing the forest cover in the foothills of many European countries over the past few decades (Bowena et al., 2007).

In the Baltic countries, the process of using former agricultural lands for the cultivation of tree species also takes place. This is one of the most popular measures for the use of abandoned agricultural land In Lithuania, thanks to which they can be involved again in economic circulation. In Estonia, attempts are also made to use abandoned land for afforestation, and the possibility of using abandoned land in the field of bioenergy is being considered (Kukk et al., 2010).

In Latvia, especially since 1990, the appearance of abandoned lands and natural growth of forests have become an integral part of the Latvian rural landscape (Ruskule et al., 2012).

In North America, in Canada and the US, as well on agricultural land where, due to economic reasons, it is not profitable to grow agricultural products, plantations from various tree species are created to expedite the production of woody biomass (Bowena et al., 2007; Flinn \& Vellend, 2005).

The studies carried out show that in Canada due to efforts to afforest agricultural land, highly productive forests can be restored and it is recommended to use local coniferous species for afforestation as the first step towards the restoration of coniferous forests in the areas that have been converted for agriculture and subsequently abandoned (Shi, 2010). In some regions of the USA, forests on former agricultural lands account for up to $80 \%$ of the current forest cover (Foster, 1992; Grashof-Bokdamand \& Geertsema, 1998).

In South America, the use of this category of land for forest growth can be noted in Mexico (MuñizCastro, Williams-Linera, \& Benay, 2006). Natural regeneration is investigated in abandoned old fields after intensive use of agricultural land in the areas originally covered by the Brazilian Atlantic forests (Silvestrini et al., 2012).

In Russia, this problem is also relevant at the present time. According to different estimates, from 40 to 50 million hectares of land have been derived from active agricultural production since 1991. More than a million hectares of postagrogenic land in many regions of the country were overgrown with tree and shrub vegetation. In many areas of the postagrogenic land, full-scale coniferous stands are formed (Utkin et al., 2002; Paramonov \& Gryazkin, 2006; Romanenko, 2008; Golubeva, 2015; Telesnina, 2015; Danilov et al., 2016; Novoselova, Zalesov, \& Magasumova, 2016; Yurovskih \& Magasumova, 2017). The process of renewal of tree vegetation on former agricultural lands is particularly active in the European part of Russia. In the North-West region, according to different data in Pskov, Novgorod, and Leningrad regions, more than a third of the agricultural land has already been renewed by tree species (Lyury, Goryachkin, \& Karavaeva, 2010). This trend is also observed in the Arkhangelsk region and Karelia (Sokolov, 1978; Golubeva, 2015).

The study of the qualitative and quantitative characteristics of the stands of pine and spruce growing on former agricultural lands has not so many publications. A small number of works have been published on this issue in Western Europe. A number of works have been published in Belarus on the topic of growing pine and birch on sandy loamy soils, derived from agricultural use. In Russia, it is necessary to note the works of Lohov, 2011; Golubeva, 2015; Danilov, 2015, and others, in which the taxation characteristics of pine and spruce stands growing on old plow lands were considered. Particularly noteworthy are the studies on the accelerated cultivation of pine and spruce on postagrogenic lands in Pskov and Leningrad regions. In the works of Sennov (2003) and Alyatin (2006), spruce forests that were renewed on the former arable lands of the Leningrad region are considered, which are characterized by increased productivity and have a stock of $300-500 \mathrm{~m}^{3}$ to the age of $80-100$ years.

Thus, the problem of pine and spruce stands growing on postagrogenic lands and their management is relevant for the science and practice of forestry.

\section{Materials and Methods}

The experimental sites are located in the northwestern part of the taiga-forest zone, which determines the dominance of sod-podzolic soils in the soil cover and is confined to the landscape area of the northern part of the Oredezhsky plateau on Devonian sandstones. We examined the areas of mixed coniferous pine and spruce stands that were renewed on former arable lands in the early forties of the last century and have reached the age of 7080 in the Gatchina district of the Leningrad region $\left(59^{\circ} 20^{\prime} 07.84^{\prime \prime} \mathrm{N} \quad 30^{\circ} 09^{\prime} 12.35^{\prime \prime} \mathrm{E} / 5^{\circ} 20^{\prime} 17.8^{\prime \prime} \mathrm{N}\right.$ $\left.30^{\circ} 09^{\prime} 20^{\prime \prime} \mathrm{E}\right)$. The sample areas under study have similar thickness of stand $(600-650$ trees per ha). Masses of stones along the edges of former arable fields point to the fact that the areas were previously used for agriculture, which is also confirmed by the cartographic data of the Russian Empire of the early twentieth century. This forest area is located within the elevated sand watershed of the Oredezh River.

Growth plots of $0.3-0.5$ hectares have been laid using portable GPSMAP 64 navigators, with boundary markers. Varying the sizes of the registration areas is connected with the necessary quantity of coniferous trees on a sample of at least 250 pieces. 
The valuation of the stand has been carried out according to the methods generally accepted in silvicultural surveys. To determine the age, Pressling's incremental drill was used to take bore cores by the root neck of the trees according to the steps of the diameter classes. From each diameter class, two cores were taken to determine the average age. On each plot, at least 30 cores were taken. Cores were polished and processed on a scanning device with resolution 1200 dots per inch, allowing for high-resolution pictures. This was followed GIS-treatment to determine quantity of annual rings using Panorama 10 software. Soil profile cuts were made on each experimental site in order to determine the granulometric composition and the thickness of the soil horizons.

The obtained quantitative data of the biometric parameters of the stand were processed with the help of a package of applied computer programs. To determine the competitive interaction between species, asymmetry and excess coefficients were calculated. Statistical processing was carried out by means of the program Statistica 11. To determine normality of data distribution, Shapiro-Wilk's W-test was used. The results obtained were subjected to ANOVA, correlation and rank analyses.

\section{Results and Discussion}

Analysis of soil sections on experimental sites showed a clear relationship between the prevalence of pine or spruce depending on the underlying rock. The stand with a predominance of pine is confined to the postagrogenic soil underlain by sandy loam and spruce dendrocenosis grows on a postagrogenic soil that has preserved arable horizon of $20-30 \mathrm{~cm}$ thickness with traces of podsolization, since a pronounced layer of forest soil with a thickness of up to $10 \mathrm{~cm}$ was formed on the top. For a pine stand, the arable horizon has a smaller thickness of $15-20$, and the process of podsolization is less pronounced on it - there are no obvious whitish stains. The soil horizon formed during the growth of the pine stand is $5-7 \mathrm{~cm}$ thick.

The conditions for the growth of these stands correspond to $\mathrm{I}^{\mathrm{a}}$ quality class for coniferous stands of spruce and pine for the region of study as well as the age. The average reserves of quality class I stands growing on forest lands in the study area at this age make up from 396 to $417 \mathrm{~m}^{3}$ for pure pine stands and from 411 to $457 \mathrm{~m}^{3}$ for spruce. For modal mixed stands with a predominance of the pine stock is 260 $\mathrm{m}^{3}$, and for a larger share of the spruce, the reserve is $300 \mathrm{~m}^{3}$ on forest lands in the most productive growing conditions. The data of forest stand valuation given in Table 1 show that the average height and diameter of pine and spruce stands exceed those of the modal pine and spruce stands and correspond to those of pure stands of these species. It is significant that the stocks of the examined stands are higher than those in the pure stands of pine and spruce. The largest reserve

Table1

Taxation characteristics of pine and spruce stands on postagrogenic lands

\begin{tabular}{|c|c|c|c|c|c|c|c|}
\hline \multicolumn{8}{|c|}{ Research object \#1. With a predominance of spruce } \\
\hline Species & Composition, \% & A, years & $\mathrm{D}_{\mathrm{av}}, \mathrm{cm}$ & $\mathrm{H}_{\mathrm{av}}, \mathrm{m}$ & $\mathrm{G}, \mathrm{m}^{2}$ & N/ha & $\mathrm{M}, \mathrm{m}^{3}$ \\
\hline Spruce & 87 & 80 & 32.5 & 30.2 & 31.5 & 380 & 431 \\
\hline Pine & 11 & 85 & 35.7 & 27.9 & 4,9 & 50 & 55 \\
\hline Aspen & 0.5 & 50 & 17.4 & 21.7 & 0.2 & 7 & 2 \\
\hline Birch & 1.5 & 60 & 19.4 & 22 & 1 & 33 & 9 \\
\hline Total: & & & 32.6 & 30 & 37.5 & 470 & 497 \\
\hline \multicolumn{8}{|c|}{ Research object \#2 With spruce predominance } \\
\hline Spruce & 55 & 80 & 27.1 & 28.2 & 23.3 & 405 & 309 \\
\hline Pine & 38 & 85 & 35.2 & 27.8 & 18.9 & 197 & 215 \\
\hline Aspen & 5 & 50 & 29.3 & 25.7 & 2.3 & 34 & 27 \\
\hline Birch & 2 & 60 & 18.0 & 21.6 & 1.4 & 54 & 14 \\
\hline Total: & & & 30.1 & 28.0 & 45.9 & 690 & 565 \\
\hline \multicolumn{8}{|c|}{ Research object \#3. With pine predominance } \\
\hline Pine & 59 & 85 & 31.2 & 27.4 & 24 & 316 & 269 \\
\hline Spruce & 32 & 80 & 21.8 & 25.4 & 11.8 & 316 & 148 \\
\hline Aspen & 4 & 50 & 33.8 & 26.2 & 1.4 & 16 & 18 \\
\hline Birch & 5 & 60 & 24.6 & 24.7 & 2 & 41 & 22 \\
\hline Total: & & & 27.8 & 26.5 & 39.2 & 689 & 457 \\
\hline
\end{tabular}




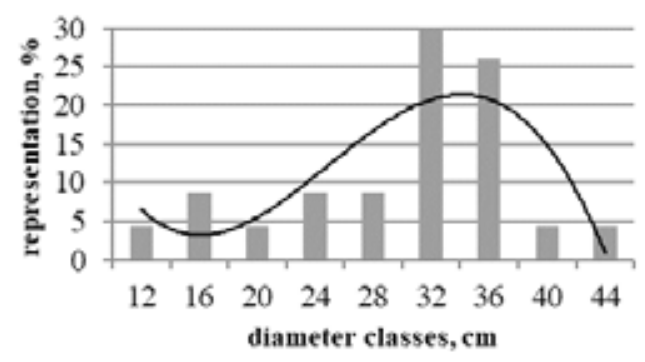

Figure 1. Pine sample plot \#1

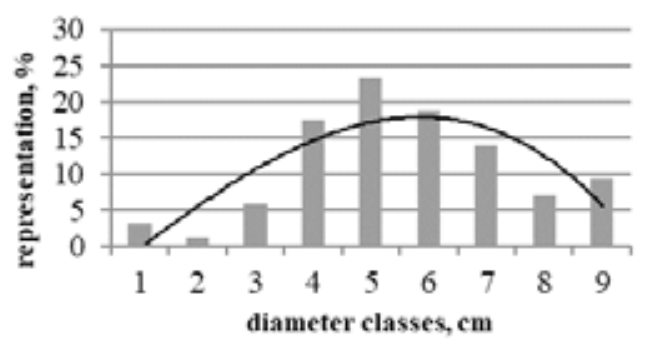

Figure 2. Pine sample plot \#2

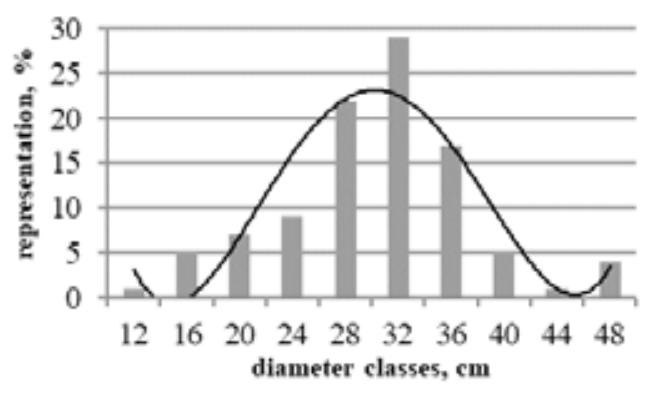

Figure 3. Pine sample plot \#3

of the conifers on the $514 \mathrm{~m}^{3}$ plantation on the plots under study is observed with a share of spruce being more than $55 \%$ in the stand and $38 \%$ of pine.

For coniferous stands growing on former arable land, the distribution series for class diameters for pine and spruce differ depending on the prevalence of this or that rock (Figs. $1-3$ ). The distribution of trees by class diameters of the pine part of the stand varies with the increase in the composition of pine plantation from abnormal to normal distribution. For a stand where spruce dominates in the composition, the series of tree distribution by class diameters has a normal distribution schedule. As the share of spruce in the stand composition decreases, the distribution diagram acquires a left slope of curve. This can be explained by the greater participation of trees of smaller thicknesses that belong to the younger spruce generation and are 10 - 20 years younger than the main maternal canopy. It is likely to be associated with the greater translucence of the pine canopy under which spruce grows successfully, whereas under the maternal canopy there is a competition for photosensitive resources.

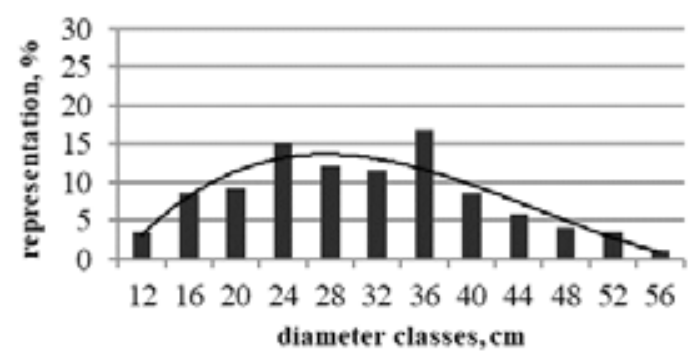

Spruce sample plot \#1.

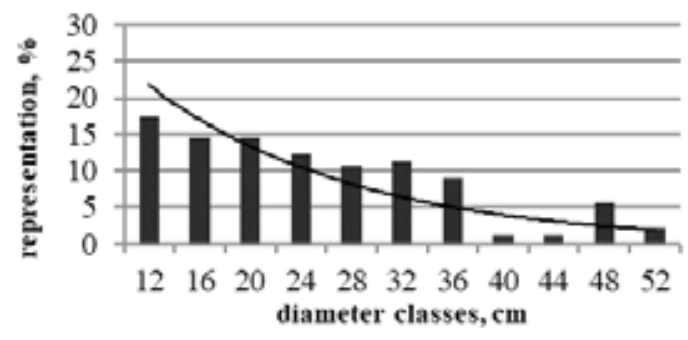

Spruce sample plot \#2.

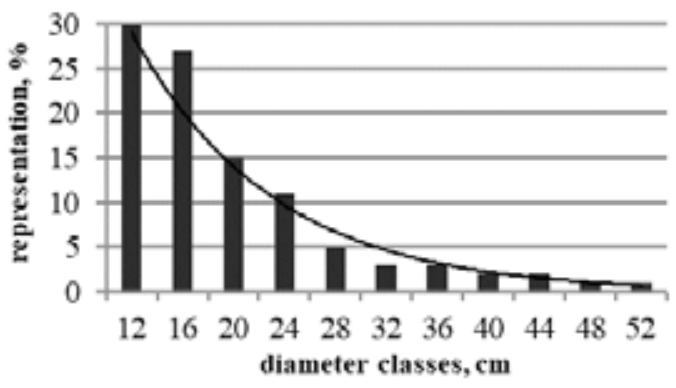

Spruce sample plot \#3.

In previous studies (Danilov \& Ishuk, 2014), the distribution of pine trees according to the diameter class in mixed coniferous stands that were not affected by logging is different from that in the stands of the same age on postagrogenic lands that we examined. On the forest lands, when the pine element is dominating in a mixed stand, we observed the left slope in the curve in the distribution diagrams and lesser representation of trees in the diameter class because of the loss of trees. The distribution diagrams of rows of spruce trunks in forest phytocenoses have a reverse difference from the examined stands. With an increase in the proportion of spruce in the stand composition, the distribution diagram shows the right slope of the curve, which is indicative of a fewer number of trees belonging to smaller thickness steps of trunks.

The skewness index of the distribution series along the thickness steps can be considered as a quantitative indicator of the development measure of the stand and the intensity of interspecies relations.

The distribution curves of trees by diameter show the degree of cenotic heterogeneity of a particular 
Indicators of skewness and kurtosis coefficients in the distribution curves of the stand diameter classes on experimental plots in coniferous stands

\begin{tabular}{|l|c|c|c|c|c|c|}
\hline \multirow{2}{*}{ Sample plot } & \multicolumn{2}{|c|}{1} & \multicolumn{2}{c|}{2} & \multicolumn{2}{c|}{3} \\
\cline { 2 - 7 } & spruce & pine & spruce & pine & spruce & pine \\
\hline Skewness & -0.917 & 0.762 & -1.338 & -1.182 & 0.266 & 0.198 \\
\hline Kurtosis & 0.270 & 1.499 & -0.262 & 0.438 & 1.292 & 1.131 \\
\hline
\end{tabular}

stand. Experimental distribution curves with respect to diameter do not always follow the law of normal distribution. The calculated indicators of skewness and kurtosis for mixed coniferous stands were interpreted from the ecological and silvicultural points of view on the basis of the above provisions. The values of the skewness and kurtosis coefficients are reliable at the $5 \%$ level.

The analysis of the indices given in Table 2 allows us to conclude that, in principle, with negative skewness of the distribution series over the thickness steps, it is considered that competition in the studied stands is minimal only for the sample plot No. 2. The normal distribution series over the thickness steps of the stand during the growth and development of the plantation can pass into a distribution with a negative skewness in a number of cases. In one case - in the context of slight loss of trees from smaller steps and with a decrease in the growth rate of leader trees against the background of intensification of growth processes in trees of central thickness steps. In the other case - in the context of the loss of trees from the upper thickness steps and a uniform change in the increment in the lower and middle steps.

The formation of a positive skewness in the distribution curve is also possible as a result of the action of various biological processes as a result of the weakening of the stand from the effects of diseases and pests. In general, the decrease in skewness prevails when specific stands are approaching the border of physiological growth opportunities. Apparently, these processes take place in the experimental objects No. 1 and No. 2. The predominance of certain coniferous species in the stands leads to an aggravation of competition, which reflects the positive coefficients of skewness.

A great informative load is borne by the nature of the kurtosis of the variation curve of distribution of one or another taxation feature of the stand. The pronounced negative kurtosis of the stand distribution with a uniform age composition may indicate the effect on the tree cenosis of the disruptive selection, i.e. the trees of the lowest or largest steps of thickness predominate. With a strong positive kurtosis, it is possible to tighten the stabilizing selection in the stand, which can be observed on the sample plot No. 3 , where this indicator is maximum for both species. If the tree cenosis is well adapted to these growth conditions, then the main effect of the competitive selection results in the loss of smaller or less stable and weakened trees.

In general, the indicators of skewness and kurtosis in the distribution series clearly show an increase or decrease and weakening of competitive interaction within the stand, i.e., the qualitative side.

\section{Conclusions}

1. The research has shown that the formation of mixed coniferous stands on former old-arable lands has its specific features that differ from those of similar coniferous stands growing on forest soils that were not affected by economic impact. Highly productive stands growing on postagrogenic lands have the wood stock corresponding to that of natural 100 - 120-year-old stands.

2. The structure of mixed coniferous stands on postagenogenic lands differs from that of stands on forest soils. The quantitative representation of trees along the plantation stages on such lands is different from forest stands.

3. Competitive relationships between species are more balanced in the stand composition consisting of more than half of the spruce and about $40 \%$ of the pine, which results in the largest volume of trunk wood as compared with the plots where the proportion of these species is of prevailing importance.

4. These stands on postagrogenic lands require the development of their own management guidelines.

\section{References}

1. McDonald, D., Crabtree, J.R., Wiesinger, G., Dax, T., Stamou, N., Fleury, P., ... Gibon, A. (2000). Agricultural abandonment in mountain areas of Europe: environmental consequences and policy response. Environ. Manage., 59, 47-69. 
2. Hansen, M.C., Stehman, S.V., \& Potapov, P.V. (2010). Quantification of global gross forest cover loss. Proc. Natl. Acad. Sci. U. S. A., 107, 8650-8655.

3. Graf, R.F., Bollmann, K., Suter, W., \& Bugmann, H. (2005). The importance of spatial scale in habitat models: capercaillie in the Swiss Alps. Landscape Ecology, 20, 703-717.

4. Macků, J. (2006). Strategy and criterions for selection of reforestation agricultural plots. In: Neuh Öferová(ed.): Proc. Agricultural Land Afforestation, a Challenge to Forestry Sector. January 17, Kostelec nad Černými lesy.

5. Holubík, O., Podrázský, V., Vopravil, J., Khel, T., \& Remeš, J. (2014). Effect of agricultural lands afforestation and tree species composition on the soil reaction, total organic carbon and nitrogen content in the uppermost mineral soil profile. Soil \& Water Res., 9, 192-200.

6. Kozak, J. (2010). Reforesting Landscapes. Reforesting Landscapes Link. Pattern Process, Landscape Series, 10, 253-273.

7. Bowena, M.E., McAlpinea, C.A., House, A.P.N., \& Smith, C.G. (2007). Regrowth forests on abandoned agricultural land: A review of their habitat values for recovering forest fauna. Biological Conservation, 140, 273-296. DOI: 10.1016/j.biocon.2007.08.012.

8. Kukk, L., Astover, A., Muiste, P., Noormets, M., Roostalu, H., Sepp, K., \& Suuster, E. (2010). Assessment of abandoned agricultural land resource for bio-energy production in Estonia. Acta Agriculturae Scandinavica Section B, Soil and Plant Science, 60, 166-173.

9. Ruskule, A., Nikodemus, O., Kasparinska, Z., Kasparinskis, R., \& Brūmelis, G. (2012). Patterns of afforestation on abandoned agriculture land in Latvia. Agroforestry Systems, 85, 215-231.

10. Flinn, M.K., \& Vellend, M. (2005). Recovery of forest plant communities in post-agricultural landscapes. Frontiers in Ecology and the Environment 3, Issue 5, 243-250. DOI: 10.1890/1540-9295(2005)003.

11. Shi, Z. (2010). Afforestation and stand age affected soil respiration and net ecosystem productivity in hybrid poplar plantations in central Alberta, Canada. A thesis submitted to the Faculty of Graduate Studies and Research in partial fulfillment of the requirements for the degree of Master of Science in Soil. Science. Edmonton. Alberta, 142 p.

12. Foster, D.R. (1992). Land-use history (1730-1990) and vegetation dynamics in central New England, USA. J Ecol, 80, 753-72.

13. Grashof-Bokdam, C.J., \& Geertsema, W. (1998). The effect of isolation and history on colonization patterns of plant species in secondary woodland. J. Biogeogr 25, 837-46.

14. Muñiz-Castro, M., Williams-Linera, \& Benay, G. (2006). Distance effect from cloud forest fragments on plant community structure in abandoned pastures in Veracruz, Mexico. Journal of Tropical Ecology, 22, n.4, 431-440.

15. Silvestrini, M., Cysneiro, A.D., Lima, A.L., Veiga, L.G., Isernhagen, I., Tamashiro, J.Y., ... Rodrigues, R.R. (2012). Natural regeneration in abandoned fields following intensive agricultural land use in an Atlantic forest island, Brazil. Revista Árvore, Viçosa-MG, 36, n.4, 659-671.

16. Utkin, A.I., Gulbe, T.A., Gulbe, Ya.I., \& Ermolova, L.S. (2002). О наступлении лесной растительности на сельскохо-зяйственные земли в верхнем Поволжье (On the invasion of forest vegetation on agricultural lands in the upper Volga region). Forest Science.5, 44-52. (in Russian).

17. Paramonov, S.G., \& Gryazkin, A.V. (2006). Особенности начальной стадии облесения сельхозугодий Псковской области (Features of the initial stage of afforestation of farmland in the Pskov Region). Agrarian Science for Agriculture: a collection of articles - Barnaul: AGAU Publishing House, Book 3, 382-384 (in Russian).

18. Romanenko, G.A. (2008). Агроэкологическое состояние и перспективы использования земель России, выбывших из активного сельскохозяйственного оборота (Agroecological state and prospects for the use of land withdrawn from active agricultural use). Moscow: Federal State "Rosinformagroteh", 64 c. (in Russian).

19. Golubeva, L.V. (2015). Лесоводственно-экологическая трансформация постагрогенных земель на карбонатных отложениях в подзоне средней тайги Архангельской области (Forestry-ecological transformation of postagrogenic lands on carbonate deposit soils in subzone of middle taiga of Archangelsk region). Doctoral thesis of agriculture sciences, Archangelsk, 160 c. (in Russian).

20. Telesnina, V.M. (2015). Постагрогенная динамика растительности и свойств почвы в ходе демутационной сукцессии в южной тайге (The post-aggrogenic dynamics of vegetation and soil properties during demutational succession in the southern taiga). Forest Science №4 2015, 293-306. (in Russian). 
21. Danilov, D.A., Zhigunov, A.V., Krasnovidov, A.N., Ryabinin, B.N., Neverovsky, V.Yu., Shestakova, T.A., ... Anders, O.O. (2016). Выращивание древесных насаждений на постагрогенных землях (Growing of tree stands on post-agrogenic lands). Saint Petersburg: Publishing house of Polytechnic University, 130 c. (in Russian).

22. Novoselova, N.N.,Zalesov, S.V., \& Magasumova,A.G.(2016). Формирование древесной растительности на бывших сельскохозяйственных угодьях (Formation of woody vegetation on former agricultural lands). Ekaterinburg: Publishing house of Ural state forestry university, 106 c. (in Russian).

23. Yurovskih, E.V., \& Magasumova, A.G. (2017). Живой напочвенный покров на бывших сельскохозяйственных угодьях (Living ground cover on former agricultural lands) - Agrarian Bulletin of the Urals 09 (163), 69-74. (in Russian).

24. Lyury, D.I., Goryachkin, S.V., \& Karavaeva, N.A. (2010). Динамика сельскохозяйственных земель России в XX веке и постагрогенное восстановление растительности и почв (The dynamics of agricultural lands in Russia in the 20th century and the postagrogenic restoration of vegetation and soils). Moscow: GVOS, 416 c. (in Russian).

25. Sokolov, N.N. (1978). Рост и продуктивность сосновых древостоев по старым пашням (Growth and productivity of pine stands on old arable land). News of higher educational institutions "Lesnoy zhurnal", 4, 22-25. (in Russian).

26. Lohov, D.V. (2011). Лесоводственная оценка и показатели качества древесины культур сосны на залежных землях (Forestry assessment of the pine wood quality in silvicultures on the postagrogenic lands). Ecological problems of the North: collection of scientific papers. Vol. 14, 73-76. (in Russian).

27. Danilov, D.A. (2015). Growing tree plantations of pine and spruce on the grounds postagrogenic Northwest Towards a Sustainable Bioeconomy 21-23 October 2015, Sant Pau, Barcelona, 37-42.

28. 28. Sennov, S.N. (2003). Рост хвойных древостоев в зависимости от происхождения (The growth of coniferous stands depending on their origin). Moscow: Forest sciences 4, 111-119. (in Russian).

29. Alyatin, M.V. (2007). Особенности происхождения, формирования и воспроизводства сложных ельников Ижорского (Силурийского) плато (Features of origin, formation and regeneration of complex spruce stands of Izhora (Silurian) plateau). Doctoral thesis of agriculture sciences, Saint-Petersburg, 165 c. (in Russian).

30. Danilov, D.A., \& Ishuk, T.A. (2014). Определение конкурентных взаимоотношений в смешанных древостоях. Методы и анализ (Determination of competitive relationships in mixed forest stands. Methods and analysis). Saarbrucken: LAP LAMVERT Academic Publishing. (in Russian). 